\title{
PENGENTASAN KEMISKINAN MELALUI USAHA INDUSTRI KECIL MENENGAH DI KABUPATEN MAGELANG
}

\author{
Dinar Melani Hutajulu ${ }^{1)}$, Fitrah Sari Islami ${ }^{2)}$, Rian Destiningsih ${ }^{3)}$ \\ ${ }^{1}$ Fakultas Ekonomi, Universitas Tidar \\ email: dinarmelani@untidar.ac.id \\ ${ }^{2}$ Fakultas Ekonomi, Universitas Tidar \\ email: fitrahsari@untidar.ac.id \\ 3 Fakultas Ekonomi, Universitas Tidar \\ email: riandestiningsih@untidar.ac.id
}

\begin{abstract}
The poverty condition in Magelang Regency is still considered high, reaching 10.67 percent of the total population in Magelang Regency. This number still lags behind the national average of 9.41 percent. This is also not in accordance with the 2014-2019 RPJMD target of Magelang Regency where the percentage of poverty is expected to touch 9 percent. The purpose of this study was to determine how small and medium industrial enterprises influence poverty alleviation in Magelang Regency. The research was conducted in Magelang Regency using secondary data for 20 years from 2000 - 2019. The method of analysis used ordinary least squares. The results show that all variables have a simultaneous effect on poverty alleviation efforts in Magelang Regency. However, partially, there are only a few variables that have an influence on poverty alleviation, such as the total of SMIEs, SMIEs employment and the investment value of SMIEs.
\end{abstract}

Keywords: poverty, SMIEs, SMIEs employment, investment value

\section{PENDAHULUAN}

Kemiskinan telah menjadi dasar pemerintah dan berbagai daerah untuk terus menerus mencari solusi dalam pengurangan kemiskinan tersebut. Hal ini dikarenakan kondisi kemiskinan merupakan cerminan dari keadaan kesejahteraan penduduk suatu daerah pada umumnya. Semakin sedikit persentase jumlah penduduk miskin di suatu daerah mengindikasikan semakin sejahtera penduduk daerah tersebut dan semakin besar persentase kemiskinan di suatu daerah maka mengindikasikan ketidaksejahteraan penduduk daerah tersebut [1].

Berbagai upaya pengentasan kemiskinan telah banyak dilakukan pemerintah selama beberapa tahun terakhir. Penanganan secara spesifik dilakukan pemerintah terhadap indikator penanggulangan kemiskinan yang telah ditetapkan yaitu akses kesehatan, pendidikan, dan standar kualitas hidup [2]. Namun banyak dari program-program pengentasan kemiskinan seperti pemberian dana tunai maupun akses pada pendidikan gratis dan kesehatan yang murah, belum sepenuhnya menanggulangi permasalahan kemiskinan secara umum termasuk di daerahdaerah di Indonesia. Kondisi kemiskinan di Kabupaten Magelang dinilai masih tinggi dengan menyentuh angka 10,67 persen dari keseluruhan penduduk kabupaten. Kondisi ini selama enam tahun terakhir memang mengalami penurunan sekitar 1,98 persen [3]. Rata-rata penurunan yang terjadi selama 6 tahun terakhir berkisar hanya 0,33 persen saja. 
Gambar 1. Persentase Penduduk Miskin Kabupaten Magelang dan Indonesia Tahun 2014-2019

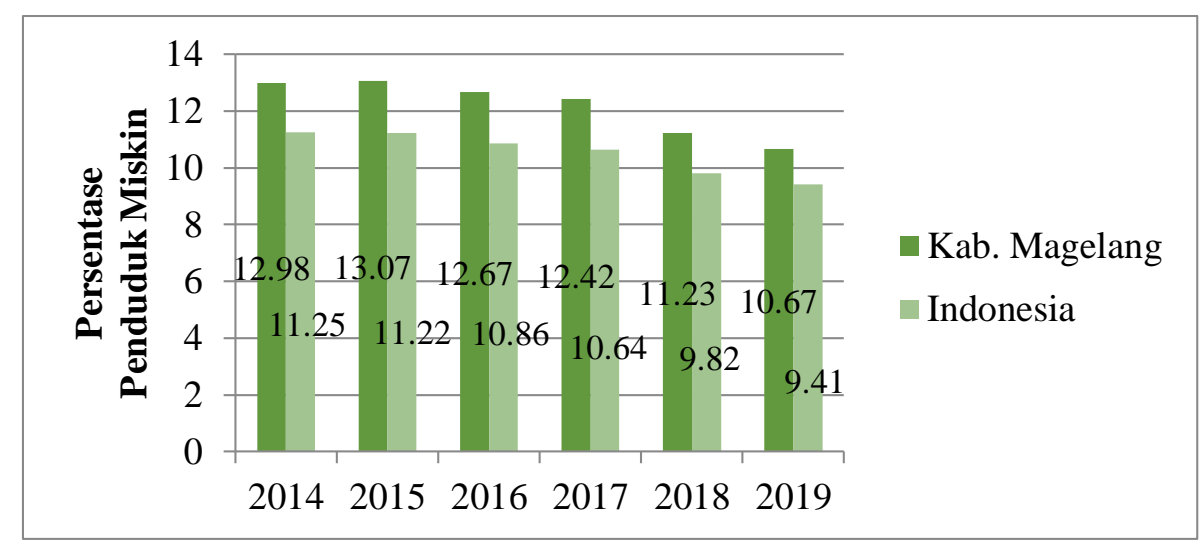

Sumber : BPS Kabupaten Magelang (diolah)

Namun hal ini tidak sesuai dengan target RPJMD Kabupaten Magelang tahun 2014-2019 dimana persentase kemiskinan diharapkan menyentuh angka 9 persen [4]. Terlihat dari tingginya tingkat kemiskinan yang menyentuh 10,67 persen, jumlah ini masih tertinggal dari rata-rata nasional sebesar 9,41\%. Masalah kemiskinan di Kabupaten Magelang jelas merupakan masalah yang harus diatasi baik oleh pemerintah maupun pemangku kepentingan lainnya di daerah maupun pusat.

Dalam menjawab permasalahan diatas, sejumlah strategi penanggulangan kemiskinan diantaranya seperti kebijakan perlindungan sosial yang lebih baik, perbaikan akses terhadap layanan primer, pemberdayaan masyarakat menengah ke bawah dan penciptaan pembangunan yang menjadi beberapa cara yang memungkinkan oleh bappeda kabupaten magelang [5]. Aspek yang sering memperparah kemiskinan di kabupaten ini yaitu lemahnya pendidikan dan akses pelayanan masyarakat miskin yang masih rumit menyebabkan programprogram diatas tidak dapat secara langsung mengurangi tingkat kemiskinan.

Dijelaskan pula hal lain yang mendukung lambatnya penanganan kemiskinan di daerah tersebut dikarenakan data base kemiskinan belum sepenuhnya digunakan dalam penanggulangan kemiskinan, efektifitas kegiatan intervensi penanggulangan kemiskinan, kurangnya keterlibatan (perguruan tinggi, pengusaha, masyarakat), kemiskinan kultural (malas, tidak mau berkembang), dan kendala aturan hibah [6].

Bappeda Kabupaten Magelang menyatakan cara lain yang sampai saat ini masih terus dilakukan sejak tahun 2014 yaitu pendampingan masyarakat miskin dalam kegiatan pengolahan produk makanan sampai kepada perijinan dan pemasaran. Kemudian pelatihan berbagai kegiatan usaha termasuk perbengkelan dan pemanfaatan pekarangan untuk berbagai jenis usaha-usaha kecil lainnya yang sesuai potensi masyarakat. Dari penuturan diatas terlihat bahwa salah satu sektor yang memiliki potensi dalam membantu pengentasan kemiskinan di Kabupaten Magelang yaitu dengan keberadaan usaha industri kecil menengah pada daerah tersebut.

Jika dilihat dari segi struktur ekonomi Indonesia, IKM merupakan kegiatan yang menunjang produktivitas masyarakat sehingga menjadi struktur dominan dalam ekonomi nasional. IKM juga sering dihubungkan kedalam sosial dan ekonomi yaitu persentase kemiskinan yang tinggi, peningkatan pengangguran pada masyarakat yang memiliki pendidikan rendah, ketidakmerataan pendapatan masyarakat, serta ketimpangan pembangunan antar daerah. Hal yang paling dirasakan dari kehadiran IKM yaitu kemampuan pengurangan jumlah pengangguran 
dan kemiskinan dengan cara menyerap tenaga kerja yang banyak [7].

Memberikan kemajuan terhadap IKM tentu saja akan menunjang penyerapan tenaga kerja sehingga berdampak pada peningkatan kesejahteraan masyarakat dan secara tidak langsung telah mengurangi pengangguran dan kemiskinan [8], [9].

Jumlah IKM tercatat cukup tinggi di Kabupaten Magelang yaitu sekitar 39.772 unit pada tahun 2018 di 21 kecamatan dan menghasilkan berbagai produk seperti makanan olahan seperti frozen food, kuliner dan jajanan lokal, kerajinan batik dan pertokoan kecil serta potensi lainnya. Pada tahun 2018, keberadaan IKM telah menyerap lebih kurang 100.000 tenaga kerja.

Selain itu, nilai investasi IKM di Kabupaten Magelang telah mencapai lebih dari 324 milyar rupiah dan nilai produksi mencapai 2 triliun rupiah pada tahun 2019. Berdasarkan data tersebut, terjadi peningkatan dari tahun ke tahun pada sektor IKM di Magelang dengan harapan yang besar dari pemerintah bahwa IKM akan mampu mengurangi pengangguran dan mengentaskan kemiskinan.

Berdasarkan hal diatas, maka masalah yang teridentifikasi yaitu masih tingginya tingkat kemiskinan di Kabupaten Magelang. Tingginya tingkat kemiskinan ini melebihi tingkat kemiskinan skala nasional. Program-program pemerintah yang berkaitan dengan akses pendidikan gratis, kesehatan murah dan bantuan langsung dana tunai belum juga ampuh dalam mengentaskan kemiskinan. Besarnya jumlah IKM, tenaga kerja, tingkat pendidikan, investasi, dan produksi perlu untuk di analisis karena dianggap memiliki potensi. Oleh karena itu, peneliti merasa perlu untuk mengkaji bagaimanakah eksistensi IKM di Kabupaten Magelang sehingga dapat dijadikan sebagai upaya pengentasan kemiskinan di Kabupaten Magelang tersebut.

Tujuan dari penelitian ini yaitu melihat pengaruh jumlah UMKM serta keberadaan
UMKM dalam mengurangi kemiskinan, pengaruh penyerapan tenaga kerja pada UMKM dalam mengentaskan kemiskinan, pengaruh tingkat pendidikan formal dalam mengentaskan kemiskinan, pengaruh nilai investasi pada UMKM dalam mengentaskan kemiskinan, pengaruh nilai produksi pada UMKM dalam mengentaskan kemiskinan, dan pengaruh masing-masing variabel secara bersama-sama dalam mengentaskan kemiskinan.

Beberapa penelitian yang mengkaji mengenai kemiskinan dan UMKM menghasilkan penelitian dimana UMKM memiliki berpengaruh besar dalam penciptaan lapangan kerja dan mengurangi kemiskinan [10]. Dikatakan juga bahwa UMKM signifikan dalam mengurangi kemiskinan dan didukung oleh aturan-aturan kebijakan pemerintah dan perencana pembangunan [11].

Selain itu, terdapat kaitan yang signifikan antara UMKM dan tenaga kerja dalam mengurangi kemiskinan namun tidak dengan pendidikan formal [12]. Hal ini di dukung dengan pemberian kemampuan keterampilan dalam melatih masyarakat miskin untuk lebih produktif.

Penelitian lainya yang membahas pentingnya UMK dalam pengentasan kemiskinan memberikan hasil bahwa UMK memang dalam pengentasan kemiskinan, terutama didukung oleh lima indikator yaitu jumlah unit usaha, jumlah pekerja, produktivitas, pangsa output, dan nilai ekspor [13]. Hasil penelitian ini terutama memberikan makna pengentesan kemiskinan pada daerah provinsi.

\subsection{Kemiskinan}

Kemiskinan adalah suatu fenomena di masyarakat yang dapat diukur dengan berbagai cara. Berbagai cara yang telah dilakukan dalam mengukur kemiskinan yaitu dengan melihat kesejahteraan ekonomi seperti konsumsi dan penghasilan masyarakat. Sehingga seseorang yang miskin adalah seseorang yang berada dibawah standar kesejahteraan minimal yang telah ditentukan [14]. 
Dikemukan bahwa pengertian kemiskinan dari sisi pendapatan didasarkan pada pertanyaan yang diberikan oleh siapa, bagaimana pemahaman akan hal tersebut dan bagaimana serta siapa yang memberikan respon [15].

\subsection{Industri Kecil Menengah}

Bank Indonesia mengemukakan UKM adalah perusahaan industri dengan modal dibawah 20 juta, dengan total asset maksimal 600 jt dan tidak termasuk harta tidak bergerak, serta pendapatan tahunan lebih dari 1 milyar rupiah.

IKM telah memberi titik terang, perhatian dan strategi bagi pengentasan kemiskinan dan sekarang menjadi isu universal terutama di kalangan tahapan ekonomi berkembang. Selain itu, pengembangan usaha kecil dan menengah telah digambarkan sebagai mekanisme yang penting dari suatu usaha untuk peningkatan pertumbuhan serta menambah lapangan pekerjaan dan pengurangan kemiskinan [9].

\subsection{Penyerapan Tenaga Kerja}

Todaro menyebutkan bahwa penyerapan tenaga kerja yaitu tersedianya kesempatan kerja untuk para pencari kerja atau merupakan jumlah pekerja yang terserap pada suatu usaha untuk melakukan kegiatan ekonomi dan menghasilkan barang/jasa [16].

Penyerapan tenaga kerja akan semakin banyak karena adanya peluang usaha. Pemerintah setempat mendorong sektor-sektor usaha kecil untuk membuka lapangan pekerjaan demi terciptanya komoditas-komoditas baru untuk perbaikan ekonomi global [17].

\subsection{Pendidikan Formal}

Pendidikan formal ditujukan untuk meningkatkan kemampuan akademik serta disiplin diri dan peningkatan kemampuan mental serta fisik. Selain itu, mampu menunjang pengembangan diri dan kreativitas yang nantinya akan berfungsi sebagai pendukung dalam mencari pekerjaan ataupun menciptakan suatu usaha. Dapat dikatakan bahwa pendidikan formal memiliki tujuan yang dapat mensejahterahkan. Sehingga pendidikan formal merupakan prioritas dalam membantu menanggulangi kemiskinan [18].

\subsection{Nilai Investasi}

Investasi biasanya hanya berkaitan dengan pembentukan modal tetap dan stok barang [19]. Namun dalam hal ini, investasi menjadi nilai yang penting dalam UMKM karena hampir keseluruhan UMKM yang berdiri pasti membutuhkan investasi demi pengembangan usaha tersebut. Sehingga nilai investasi yang sesuai untuk prospek pengembangan UMKM akan menjadi penunjang dalam memperluas usaha, peningkatan kesempatan kerja dan pengurangan kemiskinan.

Apalagi di zaman sekarang ini, tantangan persaingan global semakin sengit, sehingga nilai investasi menjadi komponen penting juga dalam menunjang UMKM menuju persaingan global [20].

\subsection{Nilai Produksi}

Nilai produksi adalah tingkat produksi barang/jasa pada suatu usaha yang merupakan hasil akhir produksi dari usaha tersebut. Output inilah yang nantinya sampai kepada produsen. Peningkatan penjualan barang hasil produksi akan memberikan manfaat omset dan keuntungan suatu usaha. Sehingga usaha dapat berkembang, memperbanyak tenaga kerja, dan semakin memberikan kesejahteraan bagi pekerja dan unit usaha tersebut.

\subsection{Hipotesis}

Berikut di bawah ini yang akan dijadikan hipotesisi dalam penelitian ini :

H1 : Terdapat pengaruh yang signifikan antara jumlah UMKM terhadap kemiskinan di Kabupaten Magelang

$\mathrm{H} 2$ : Terdapat pengaruh yang signifikan antara penyerapan tenaga kerja terhadap kemiskinan di Kabupaten Magelang

H3 : Terdapat pengaruh yang signifikan antara tingkat pendidikan formal terhadap kemiskinan di Kabupaten Magelang 
H4 : Terdapat pengaruh yang signifikan antara nilai investasi terhadap kemiskinan di Kabupaten Magelang

H5 : Terdapat pengaruh yang signifikan antara nilai produksi terhadap kemiskinan di Kabupaten Magelang

H6 : Terdapat pengaruh yang signifikan antara jumlah UMKM, penyerapan tenaga kerja, tingkat pendidikan formal, nilai investasi, dan nilai produksi secara bersama-sama terhadap kemiskinan di Kabupaten Magelang

\section{METODE PENELITIAN}

Metode penelitian yang digunakan adalah penelitian kuantitatif. Data yang digunakan merupakan data sekunder yang disajikan oleh Badan Pusat Statistik Kabupaten Magelang dan Badan Pusat Statistik Provinsi Jawa Tengah, Dinas Perdagangan, Koperasi dan UMKM, Dinas Perindustrian dan Tenaga Kerja. Data penelitian memiliki rentang waktu 20 tahun yang diambil dari tahun $2000-2019$.

Variabel dalam penelitian ini adalah variabel independen $\left(X_{1}\right)$ jumlah IKM; variabel independen $\left(X_{2}\right)$ penyerapan tenaga kerja; variabel independen $\left(X_{3}\right)$ tingkat pendidikan formal; variabel independen $\left(X_{4}\right)$ nilai investasi pada IKM; variabel independen $\left(X_{5}\right)$ nilai produksi pada IKM; dan variabel dependen (Y) kemiskinan. Total jumlah observasi sebesar 120 data yang diambil dari enam (6) variabel penelitian dengan rentang waktu 20 tahun.

Dalam penelitian ini, variabel - variabel dapat didefiniskan sebagai berikut :

1. Jumlah unit usaha industri kecil menengah (IKM) adalah bagian dari usaha UMKM yang berdiri di Kabupaten Magelang dengan tahun penelitian dari tahun 2000-2019

2. Penyerapan tenaga kerja adalah jumlah orang/tenaga kerja yang terserap dalam oleh industri kecil menengah (IKM) di Kabupaten Magelang

3. Pendidikan formal adalah penduduk diatas 15 tahun ke atas yang menerima pendidikan berjenjang SD, SMP, dan SMA di Kabupaten Magelang

4. Nilai investasi adalah nilai investasi dalam juta rupiah pada industri kecil menengah (IKM) di Kabupaten Magelang dengan tahun penelitian dari tahun 2000-2019.

5. Nilai produksi adalah nilai produksi dalam juta rupiah pada industri kecil menengah (IKM) di Kabupaten Magelang dengan tahun penelitian dari tahun 2000-2019.

6. Kemiskinan adalah jumlah penduduk miskin dalam ribu jiwa di Kabupaten Magelang dengan tahun penelitian dari tahun 20002019.

Data disajikan dalam bentuk tabulasi secara tersusun sesuai urutan waktu dan urutan variabel masing-masing. Kemudian dilakukan pengolahan data penelitian dengan terlebih dahulu melakukan uji asumsi klasik. Uji asumsi klasik harus terpenuhi agar nantinya menghasilkan persamaan yang mengedepankan terpenuhinya Best Linear Unbiased Estimator. Uji normalitas dilakukan untuk melihat model persamaan yang diperoleh memenuhi asumsi normal. Dalam uji normalitas, jika nilai prob. Jarque-Bera > sig 0,05 maka model tersebut terdistribusi normal.

Uji autokorelasi yaitu untuk mengetahui korelasi variabel yang ada di dalam model prediksi dengan perubahan waktu. Uji Breusch Godfrey dengan melihat nilai prob. Chi-Square. Jika nilai prob. Chi-Square > 0,05 maka tidak terdapat masalah autokorelasi dalam model persamaan tersebut.

Uji ini berguna dalam melihat apakah terdapat ketidaksamaan varian dari masingmasing residual untuk semua pengamatan pada model ini. Pada uji heterokedastisitas, jika nilai prob. $\mathrm{F}>$ sig 0,05 maka model terbebas dari masalah heterokedastisitas. Uji ini dilakukan untuk melihat ada kolinearitas antar variabel bebas. Pada uji multikolinearitas, jika nilai $\mathrm{R}^{2}$ pada coefficient correlation $<0,9$, maka model terbebas dari masalah multikolinearitas. 
Metode analisis dalam penelitian ini menggunakan metode ordinary least square dengan model persamaan sebagai berikut :.

$$
\begin{aligned}
& \log (\mathrm{Y})=\alpha+\beta_{1} \log \left(\mathrm{X}_{1}+\beta_{2} \log \left(\mathrm{X}_{2)}+\right.\right. \\
& \beta_{3} \log \left(\mathrm{X}_{3)}+\beta_{4} \log \left(\mathrm{X}_{4}\right)+\beta_{5} \log \left(\mathrm{X}_{5)}+\mu\right.\right.
\end{aligned}
$$
dimana:

$\mathrm{Y} \quad=$ Kemiskinan (ribu jiwa)

$\mathrm{X}_{1} \quad=$ Jumlah IKM (unit)

$\mathrm{X}_{2} \quad=$ Penyerapan Tenaga Kerja (orang)

$\mathrm{X}_{3}=$ Tingkat Pendidikan Formal (persen)

$\mathrm{X}_{4} \quad=$ Nilai Investasi (juta rupiah)

$\mathrm{X}_{5} \quad=$ Tingkat Produksi (juta rupiah)

$\alpha \quad=$ Konstanta

$\beta_{1} \beta_{2} \beta_{3}=$ Koefisien regresi

$\mu \quad=$ Kesalahan pengganggu/ term of error

Selanjutnya dilakukan uji koefisien determinasi untuk mengetahui besarnya kemampuan variabel independen secara bersamasama dalam menjelaskan variabel dependen. Kemudian dilakukan, uji-t dilakukan untuk melihat apakah masing-masing koefisien regresi signifikan terhadap variabel dependen. Dan terakhir, uji $\mathrm{F}$ adalah uji yang dilakukan pada koefisien regresi secara simultan. Pengujian merupakan cara untuk mengetahui pengaruh keseluruhan variabel independen secara bersama-sama (simultan) terhadap variabel dependen.

\section{HASIL DAN PEMBAHASAN 3.1 Hasil Penelitian}

Masalah kemiskinan adalah persoalan dasar yang menjadi fokus pemerintah. Kemiskinan yang diukur dengan cara yang terpercaya dapat digunakan sebagai acuan yang baik dalam memberikan kebijakan pada masalah ini. Data kemiskinan yang berkualitas juga dapat dijadikan bahan untuk evaluasi kebijakan kemiskinan yang telah ada, menjadi dasar dalam menentukan target pengurangan kemiskinan, serta menjadi alat untuk melihat perubahan kemiskinan dari waktu ke waktu.

Pada dasarnya, mengukur kemiskinan dapat digunakan dengan konsep kebutuhan dasar (basic needs approach). Pendekatan ini memandang kemiskinan sebagai ciri dari ketidakmampuan secara ekonomi dalam pemenuhan kebutuhan dasar yang terukur menggunakan sisi pengeluaran. Dapat diartikan bahwa penduduk miskin adalah penduduk dengan penghasilan rata-rata pengeluaran perkapita perbulan dibawah garis kemiskinan. Di bawah ini disajikan jumlah penduduk miskin Kabupaten Magelang tahun 2000 - 2019.

Gambar 2. Persentase Penduduk Miskin Kabupaten Magelang Tahun 2000 - 2019

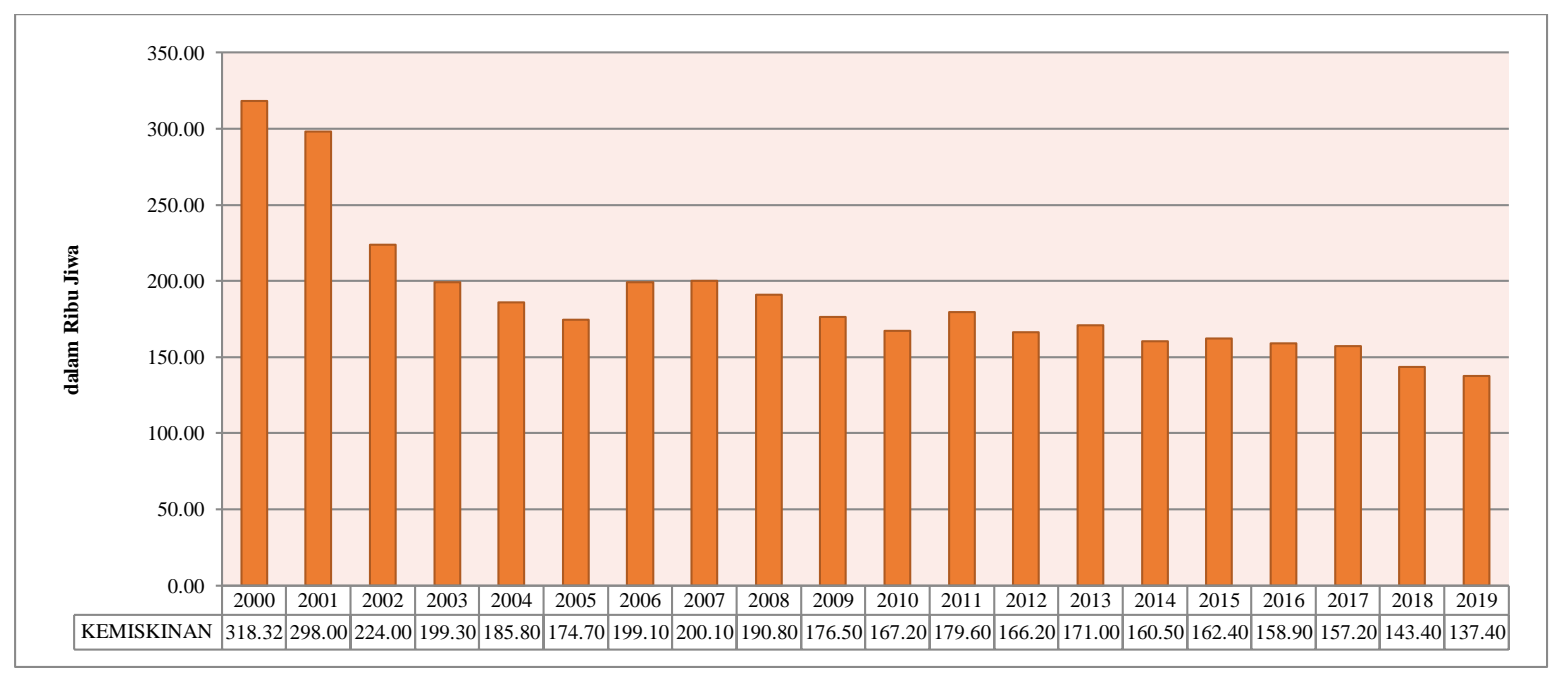


Sumber : BPS Kabupaten Magelang, diolah

Jumlah penduduk miskin Kabupaten Magelang Tahun 2000 - 2019 menunjukkan nilai yang semakin menurun. Pada Tahun 2000, di Kabupaten Magelang penduduk miskin berjumlah sebesar 318,3 ribu jiwa, turun menjadi 137,4 ribu jiwa di Tahun 2018. Hal ini menunjukkan dalam rentang waktu 20 tahun pemerintah berhasil mengentaskan penduduk miskin. Namun jika dilihat per tahun terjadi fluktuasi di tiap tahunnya. Pada level provinsi, persentase penduduk miskin Jawa Tengah selama 2009-2018 menunjukkan penurunan. Pada tahun 2009, persentase penduduk miskin mencapai 17,48 persen, kemudian turun menjadi 10,67 persen pada tahun 2019 .

Tabel 1. Persentase Penduduk Miskin Tahun 2014-2019

\begin{tabular}{|c|c|c|c|c|c|c|}
\hline \multirow{2}{*}{ Wilayah Administrasi } & \multicolumn{6}{|c|}{ Persentase Penduduk Miskin } \\
\cline { 2 - 7 } & $\mathbf{2 0 1 9}$ & $\mathbf{2 0 1 8}$ & $\mathbf{2 0 1 7}$ & $\mathbf{2 0 1 6}$ & $\mathbf{2 0 1 5}$ & $\mathbf{2 0 1 4}$ \\
\hline Kabupaten Magelang & 10,67 & 11,23 & 12,42 & 12,67 & 13,07 & 12,98 \\
\hline
\end{tabular}

Sumber : BPS Kabupaten Magelang

Kondisi kemiskinan di kabupaten ini masih cukup tinggi yaitu mencapai 10,6 persen pada tahun 2019. Tahun 2018 sebesar 11,23 persen mengalami penurunan jika dibandingkan dengan tahun 2014. Rata-rata penurunan penduduk miskin sebesasr 0,35 persen dalam lima tahun tersebut. Angka kemiskinan pada kabupaten Magelang mengalami penurunan namun jika dibandingkan dengan target yang ditetapkan dalam RPJMD pada tahun 2014-2019 dengan harapan tingkat penduduk miskin menjadi 9 persen, hal ini masih belum memenuhi.

Berdasarkan data diatas, maka dilakukan uji analisis metode ordinary least square. Namun sebelum melihat hasil persamaan dari analisis pada data penelitian ini, maka dilakukanlah uji asumsi klasik yaitu uji normalitas, uji autokorelasi, uji heterokedastisitas, dan uji multikolinearitas.

Gambar 3. Hasil Uji Normalitas

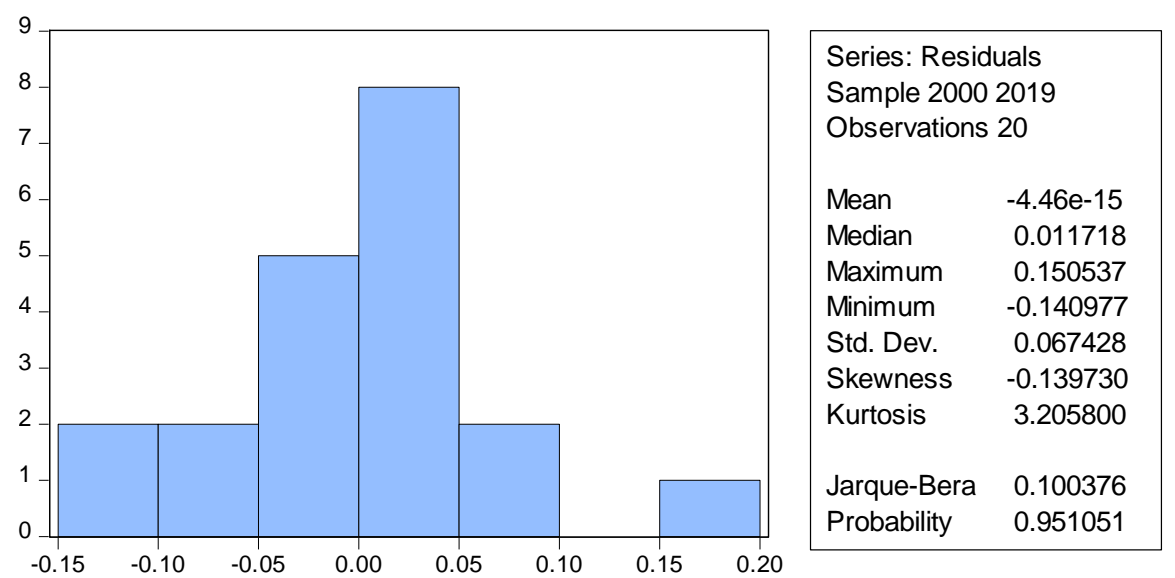

Hasil normalitas dapat dilihat pada gambar berikut. Dari hasil uji normalitas pada tabel diatas, diketahui bahwa nilai prob. JB sebesar 0,95 lebih besar dari $\alpha=0,05$. Sehingga dapat dikatakan bahwa model yang digunakan mempunyai residual yang berdistribusi normal. 
Uji autokorelasi ini dilakukan dengan melihat nilai probabilitas Chi-Square pada Breusch-Godfrey. Jika nilai prob Chi-Square lebih besar dari 0,05, maka model tidak mengalami masalah autokorelasi. Berikut hasil uji autokorelasi Breusch-Godfrey.

Tabel 2. Hasil Uji Autokorelasi

\begin{tabular}{|l|r|l|r|}
\hline \multicolumn{4}{|c|}{ Breusch-Godfrey Serial Correlation LM Test: } \\
\hline F-statistic & 0.072978 & Prob. F(2,12) & 0.9300 \\
\hline Obs*R-squared & 0.240336 & Prob. Chi-Square(2) & 0.8868 \\
\hline
\end{tabular}

Dari hasil uji autokorelasi, nilai prob Chi-Square sebesar 0,88>0,05. Dari hasil tersebut, maka dapat dikatakan model tidak mengalami masalah autokorelasi.

Uji heterokedastisitas diperlukan untuk melihat apakah terjadi gangguan heterokedastisitas pada model regresi diatas.
Untuk melihat gangguan tersebut dilakukan uji Glejser. Keputusan terjadi atau tidaknya heterokedastisitas pada model regresi linier dengan melihat prob. F-statistic. Apabila nilainya lebih besar dari alpha $0,05(5 \%)$ maka tidak terjadi heterokedastisitas dan sebaliknya.

Tabel 3. Hasil Uji Heterokedastisitas

\begin{tabular}{|l|r|l|r|}
\hline \multicolumn{4}{|c|}{ Heteroskedasticity Test: Glejser } \\
\hline F-statistic & 1.352571 & Prob. F(5,14) & 0.2998 \\
\hline Obs*R-squared & 6.514377 & Prob. Chi-Square(5) & 0.2593 \\
\hline Scaled explained SS & 5.295034 & Prob. Chi-Square(5) & 0.3809 \\
\hline
\end{tabular}

Pada tabel uji glejser diatas, terdapat nilai probabilitas sebesar 0,0000 yang berarti nilai probabilitas $0,29>0,05$. Maka tidak terdapat masalah heterokedastisitas pada model tersebut.

Tabel 4. Hasil Uji Multikolinearitas

\begin{tabular}{|c|c|c|c|c|c|}
\hline & $\log \left(\mathrm{X}_{1}\right)$ & $\log \left(\mathrm{X}_{2}\right)$ & $\log \left(\mathrm{X}_{3}\right)$ & $\log \left(\mathrm{X}_{4}\right)$ & $\log \left(\mathrm{X}_{5}\right)$ \\
\hline & & & & & \\
\hline $\log \left(\mathrm{X}_{1}\right)$ & 1.00 & 0.85 & 0.69 & 0.44 & 0.83 \\
\hline $\log \left(\mathrm{X}_{2}\right)$ & 0.85 & 1.00 & 0.78 & 0.33 & 0.93 \\
\hline $\log \left(\mathrm{X}_{3}\right)$ & 0.69 & 0.78 & 1.00 & 0.34 & 0.69 \\
\hline $\log \left(\mathrm{X}_{4}\right)$ & 0.44 & 0.33 & 0.34 & 1.00 & 0.40 \\
\hline $\log \left(\mathrm{X}_{5}\right)$ & 0.83 & 0.93 & 0.69 & 0.40 & 1.00 \\
\hline
\end{tabular}

Uji multikolinearitas dilakukan untuk melihat apakah terdapat kolinearitas antar variabel bebas. Pada uji multikolinearitas, jika nilai $\mathrm{R}^{2}$ pada coefficient correlation $<0,9$, maka model terbebas dari masalah multikolinearitas. Dari hasil uji diatas, terlihat bahwa nilai $\mathrm{R}^{2}$ antar variabel tidak terdapat yang nilainya $>0,9$. Sehingga dapat dikatakan tidak terdapat masalah multikolinearitas.
Setelah melakukan uji asumsi klasik, maka model persamaan dapat diyatakan layak untuk dijadikan model yang sesuai dan tidak bias. Dalam penelitian ini, model analisis yang digunakan adalah model Ordinary Least Square. Dari hasil analisis maka didapatkanlah estimasi model penelitian sebagai berikut.

Tabel 5. Hasil Analisis Ordinary Least Square 


\begin{tabular}{|c|r|r|r|r|}
\hline Dependent Variable: $\log (\mathrm{Y})$ \\
\hline \multicolumn{5}{|c|}{} \\
\hline Variable & Coefficient & Std. Error & t-Statistic & Prob. \\
\hline $\mathrm{C}$ & 22.630 & 2.202557 & 10.27615 & 0.0000 \\
\hline $\log \left(\mathrm{X}_{1}\right)$ & -0.519229 & 0.158377 & -3.278444 & 0.0055 \\
\hline $\log \left(\mathrm{X}_{2}\right)$ & -1.208883 & 0.331639 & -3.645178 & 0.0027 \\
\hline $\left.\log \left(\mathrm{X}_{3}\right)\right)$ & -0.203040 & 0.211306 & -0.960877 & 0.3529 \\
\hline $\log \left(\mathrm{X}_{4}\right)$ & 0.056688 & 0.025073 & 2.260964 & 0.0402 \\
\hline $\log \left(\mathrm{X}_{5}\right)$ & 0.130622 & 0.073417 & 1.779176 & 0.0969 \\
\hline \multicolumn{5}{|l|}{} \\
\hline R-squared & 0.898531 & F-statistic & 24.79471 \\
\hline Adjusted R-squared & 0.862292 & Prob(F-statistic) & 0.000002 \\
\hline
\end{tabular}

Dari hasil diatas maka dapat dibentuk estimasi persamaan model penelitian sebagai berikut :

$$
\begin{aligned}
& \log (Y)=22,63-0,51 \log \left(X_{1)}-1,20 \log \left(X_{2)}-\right.\right. \\
& 0,20 \log \left(X_{3)}+0,05 \log \left(X_{4}\right)+0,13 \log \left(X_{5)}+\mu\right.\right.
\end{aligned}
$$

Persamaan diatas menunjukkan bahwa slope pada variabel $\mathrm{X}^{1}, \mathrm{X}^{2}$, dan $\mathrm{X}^{3}$ bernilai negatif. Sedangkan pada variabel $X^{4}$, dan $X^{5}$ bernilai positif. Dari persamaan diatas terlihat bahwa $\mathrm{X}^{1}$ memiliki koefisien sebesar -0,51. Hal ini berarti bahwa jika jumlah usaha industri kecil menengah mengalami peningkatan sebesar 1 persen, maka akan mengurangi kemiskinan sebesar 0,51 persen. Pada variabel $\mathrm{X}^{2}$, nilai koefisien sebesar -1,20. Hal ini berarti bahwa jika penyerapan tenaga kerja pada usaha industri kecil menengah mengalami kenaikan sebesar 1 persen, maka hal ini menyebabkan pengurangan kemiskinan sebesar 1,20 persen. Pada variabel $\mathrm{X}^{3}$, terlihat bahwa nilai koefisien sebesar $-0,20$. Hal ini berarti bahwa jika pendidikan formal penduduk Kabupaten Magelang mengalami peningkatan sebesar 1 persen, maka akan terjadi pengurangan kemiskinan sebesar 0,20 persen.

Sedangkan pada variabel $\mathrm{X}^{4}$ terlihat bahwa nilai koefisien sebesar 0,05 . Hal ini berarti bahwa jika nilai investasi mengalami peningkatan sebesar 1 persen, maka akan menambah kemiskinan sebesar 0,05 persen. Pada variabel $\mathrm{X}^{5}$ terlihat bahwa nilai koefisien sebesar
0,13. Hal ini berarti bahwa jika nilai produksi mengalami peningkatan sebesar 1 persen, maka akan menambah kemiskinan sebesar 0,13 persen.

Hasil estimasi model persamaan diatas perlu untuk diketahui bagaimana tingkat signifikansinya dalam melihat apakah memang variabel bebas berpengaruh terhadap variabel kemiskinan di Kabupaten Magelang. Maka perlu untuk diketahui uji goodness of fit.

Koefisien determinasi dilakukan untuk melihat seberapa besar kemampuan variabel independen dalam menjelaskan variabel dependen. Jika adj-R ${ }^{2}$ semakin besar maka variabel independen memiliki pengaruh besar terhadap variabel dependen dan sebaliknya. Nilai adj- $\mathrm{R}^{2}$ pada hasil penelitian ini adalah sebesar 0,8622 . Hal ini menjelaskan bahwa variabel independen dapat menjelaskan variabel dependen sebesar 86,22 persen dan sisanya sebesar 13,78 persen dijelaskan oleh variabel lain.

Uji t dilakukan untuk melihat apakah masing-masing koefisien regresi signifikan terhadap variabel dependen dengan menganggap variabel lainnya konstan. Ho diterima ( $t_{\text {hitung }}$ $<\mathrm{t}_{\text {tabel }}$ ) atau prob. $\mathrm{t}$ statistic $>0,05$ artinya variabel independen secara parsial tidak berpengaruh nyata terhadap variabel dependen. Ha diterima ( $\left.t_{\text {hitung }}>t_{\text {tabel }}\right)$ ) atau prob. $t$ statistic $<0,05$ artinya variabel independen secara parsial berpengaruh nyata terhadap variabel dependen. 
Hasil analisis data yang dilakukan menunjukkan bahwa nilai prob. $\mathrm{t}$ statistic pada variabel $\mathrm{X}^{1}$ sebesar 0,00 . Hal ini memberikan jawaban bahwa ternyata jumlah usaha industri kecil menengah (IKM) memiliki pengaruh yang signifikan terhadap kemiskinan. Nilai prob. $\mathrm{t}$ statistic pada variabel $\mathrm{X}^{2}$ sebesar 0,00 . Hal ini memberikan jawaban bahwa ternyata penyerapan tenaga kerja pada usaha industri kecil menengah (IKM) memiliki pengaruh yang signifikan terhadap kemiskinan.

Nilai prob. $t$ statistic pada variabel $\mathrm{X}^{3}$ sebesar 0,35. Hal ini memberikan jawaban bahwa ternyata tingkat pendidikan formal tidak memiliki pengaruh yang signifikan terhadap kemiskinan. Nilai prob. $t$ statistic pada variabel $\mathrm{X}^{4}$ sebesar 0,04 . Hal ini memberikan jawaban bahwa ternyata nilai investasi pada industri kecil menengah (IKM) memiliki pengaruh yang signifikan terhadap kemiskinan. Nilai prob. $t$ statistic pada variabel $\mathrm{X}^{5}$ sebesar 0,09 . Hal ini memberikan jawaban bahwa ternyata nilai produksi pada industri kecil menengah (IKM) tidak memiliki pengaruh yang signifikan terhadap kemiskinan.

Uji $F$ dilakukan untuk mengetahui pengaruh semua variabel independen secara bersama-sama (simultan) terhadap variabel dependen. Ho diterima $\left(\mathrm{F}_{\text {hitung }}<\mathrm{F}_{\text {tabel }}\right)$ atau nilai prob. $\mathrm{F}$ statistik > 0,05 artinya variabel independen secara simultan tidak berpengaruh nyata terhadap variabel dependen. Ha diterima $\left(\mathrm{F}_{\text {hitung }}>\mathrm{F}_{\text {tabel }}\right)$ atau nilai prob. $\mathrm{F}$ statistik $<0,05$ artinya variabel independen secara simultan berpengaruh nyata terhadap variabel dependen.

Dari hasil analisis data diketahui bahwa nilai prob. F statistic sebesar $0,00<0,05$. Hal ini menunjukkan bahwa secara bersama-sama, variabel jumlah usaha industri kecil menengah (IKM), penyerapan tenaga kerja, tingkat pendidikan formal, nilai investasi, dan nilai produksi memiliki pengaruh terhadap kemiskinan di Kabupaten Magelang.

\subsection{Pembahasan}

Kemiskinan di Kabupaten Magelang berada pada posisi peringkat 20 dari 35 kabupaten/kota di provinsi Jawa Tengah. Posisi ini perlu menjadi perhatian, mengingat juga bahwa Kabupaten Magelang belum berhasil menyentuh angka sebesar 9 persen pada persentase kemiskinan di tahun 2019. Padalah Kabupaten Magelang telah menetapkan dalam RPJMD 2014-2019 untuk meraih persentase kemiskinan sebesar 9 persen. Kenyataan menunjukkan persentase kemiskinan menyentuh angka 10,67 persen pada tahun 2019.

Kegagalan pencapaian diatas, perlu untuk ditanggulangi pada tahun-tahun berikutnya. Salah satu cara dalam menanggulangi kemiskinan di Kabupaten Magelang adalah dengan melihat kiprah usaha industri kecil menengah dalam membantu pengentasan kemiskinan di Kabupaten Magelang. Menurut [9] pengembangan usaha kecil dan menengah telah digambarkan sebagai mekanisme yang penting dari suatu usaha untuk meningkatkan pertumbuhan ekonomi, penciptaan lapangan kerja dan pengentasan kemiskinan. Berdasarkan hal diatas maka penelitian ini telah menganalisis bagaimana usaha industri kecil menengah (IKM) mampu mengentaskan kemiskinan di Kabupaten Magelang.

Hasil menunjukkan bahwa variabel $\mathrm{X}^{1}$ yaitu jumlah usaha industri kecil menengah (IKM) memiliki pengaruh yang signifikan terhadap kemiskinan di Kabupaten Magelang dengan nilai prob. t-stat sebesar 0,00. Hal ini sejalan dengan penelitian [11]-[13] yang menyatakan bahwa usaha mikro kecil menengah memiliki pengaruh dalam pengentasan kemiskinan. Nilai koefisien menunjukkan bahwa jika jumlah usaha industri kecil menengah (IKM) mengalami peningkatan sebesar 1 persen, maka akan mengurangi kemiskinan sebesar 0,51 persen di Kabupaten Magelang.

Dalam hal ini, pemerintah perlu menjadikan IKM sebagai perhatian dalam upaya pengentasan kemiskinan di Kabupaten Magelang. Karena ternyata banyaknya jumlah 
usaha industri kecil menengah (IKM) telah memberikan dampak nyata pada pengurangan kemiskinan.

Tabel 6. Persentase Kemiskinan dan Jumlah Usaha Industri Kecil Menengah dalam 20 Tahun Terakhir

\begin{tabular}{|c|c|c|}
\hline Tahun & Persentase Kemiskinan & Jumlah Usaha IKM \\
\hline 2000 & 28,80 & 29.034 \\
\hline 2001 & 26,82 & 29.098 \\
\hline 2002 & 19,86 & 29.552 \\
\hline 2003 & 17,45 & 29.630 \\
\hline 2004 & 16,10 & 29.672 \\
\hline 2005 & 15,42 & 29.673 \\
\hline 2006 & 17,36 & 29.799 \\
\hline 2007 & 17,37 & 34.191 \\
\hline 2008 & 16,49 & 38.198 \\
\hline 2009 & 15,19 & 38.236 \\
\hline 2010 & 14,14 & 38.275 \\
\hline 2011 & 15,18 & 38.470 \\
\hline 2012 & 13.97 & 38.497 \\
\hline 2013 & 13,96 & 38.510 \\
\hline 2014 & 12,98 & 38.540 \\
\hline 2015 & 13,07 & 39.671 \\
\hline 2016 & 12,67 & 39.712 \\
\hline 2017 & 12,42 & 39.745 \\
\hline 2018 & 11,23 & 39.772 \\
\hline 2019 & 10,67 & 38.198 \\
\hline
\end{tabular}

Sumber : BPS Kabupaten Magelang

Hasil analisis didukung oleh data yang menunjukkan bahwa selama 20 tahun terakhir tampak terjadi penurunan kemiskinan dan peningkatan jumlah usaha industri kecil menengah. Dari hasil analisis diatas dapat dikatakan bahwa $\mathrm{H} 1$ dapat diterima dimana ada pengaruh yang signifikan antara jumlah usaha Industri Kecil Menengah (IKM) terhadap kemiskinan di Kabupaten Magelang.

Hasil menunjukkan bahwa variabel $\mathrm{X}^{2}$ yaitu tenaga kerja memiliki pengaruh yang signifikan terhadap kemiskinan di Kabupaten Magelang dengan nilai prob. t-stat sebesar 0,00 . Hal ini sejalan dengan penelitian [12], [13] yang menyatakan bahwa jumlah pekerja atau tenaga kerja memiliki pengaruh dalam pengentasan kemiskinan. Nilai koefisien menunjukkan bahwa jika penyerapan tenaga kerja pada usaha industri kecil menengah mengalami peningkatan sebesar 1 persen, maka akan mengurangi kemiskinan sebesar 1,20 persen di Kabupaten Magelang. 
Tabel 7. Persentase Kemiskinan dan Penyerapan Tenaga Kerja Selama 20 Tahun Terakhir

\begin{tabular}{|c|c|c|}
\hline Tahun & Persentase Kemiskinan & Penyerapan Tenaga Kerja \\
\hline 2000 & 28,80 & 73.985 \\
\hline 2001 & 26,82 & 75.516 \\
\hline 2002 & 19,86 & 76.891 \\
\hline 2003 & 17,45 & 78.919 \\
\hline 2004 & 16,10 & 78.019 \\
\hline 2005 & 15,42 & 78.149 \\
\hline 2006 & 17,36 & 78.577 \\
\hline 2007 & 17,37 & 80.856 \\
\hline 2008 & 16,49 & 85.264 \\
\hline 2009 & 15,19 & 86.234 \\
\hline 2010 & 14,14 & 88.037 \\
\hline 2011 & 15,18 & 88.400 \\
\hline 2012 & 13.97 & 90.436 \\
\hline 2013 & 13,96 & 91.649 \\
\hline 2014 & 12,98 & 92.225 \\
\hline 2015 & 13,07 & 96.192 \\
\hline 2016 & 12,67 & 97.551 \\
\hline 2017 & 12,42 & 100.236 \\
\hline 2018 & 11,23 & 101.337 \\
\hline 2019 & 10,67 & 99.832 \\
\hline
\end{tabular}

Hasil analisis didukung oleh data yang ada, bahwa memang selama 20 tahun terakhir, kemiskinan berkurang dan penyerapan tenaga kerja di usaha Industri Kecil Menengah terus mengalami peningkatan. Pengurangan kemiskinan sebesar 1,20 persen setiap kenaikan penyerapan tenaga kerja pada IKM adalah nilai yang cukup besar. Jika penyerapan pada IKM dapat dimaksimalkan, bukan tidak mungkin kabupaten magelang dapat meraih target persentase kemiskinan di angka 9 persen atau mungkin bisa lebih kecil dari 9 persen. Dari hasil analisis diatas dapat dikatakan bahwa $\mathrm{H} 2$ dapat diterima dimana ada pengaruh yang signifikan antara penyerapan tenaga kerja terhadap kemiskinan di Kabupaten Magelang.

Hasil menunjukkan bahwa variabel $\mathrm{X}^{3}$ yaitu tingkat pendidikan formal tidak memiliki pengaruh yang signifikan terhadap kemiskinan di Kabupaten Magelang dengan nilai prob. t-stat sebesar 0,35. Hal ini sejalan dengan penelitian [12] yang menyatakan bahwa tingkat pendidikan formal tidak memiliki pengaruh dalam pengentasan kemiskinan. Hasil ini memberikan penjelasan bahwa tingkat pendidikan formal seseorang masyarakat, tidak berpengaruh dalam 
pengentasan kemiskinan. Hal ini dikarenakan seberapa tinggi atau rendahnya tingkat pendidikan formal masyarakat. Kemiskinan dapat ditepis dengan memiliki pekerjaan yang sesuai dengan jenjang pendidikannya. Maka dari hasil diatas, dapat dikatakan bahwa H3 tidak dapat diterima karena hasil menunjukkan bahwa memang tidak terdapat pengaruh antara tingkat pendidikan formal terhadap kemiskinan di Kabupaten Magelang.

Hasil menunjukkan bahwa variabel $\mathrm{X}^{4}$ yaitu nilai investasi pada usaha industri kecil menengah (IKM) memiliki pengaruh yang signifikan terhadap kemiskinan di Kabupaten Magelang dengan nilai prob. t-stat sebesar 0,04. Namun nilai koefisien berslope negatif dan menunjukkan bahwa jika nilai investasi mengalami peningkatan sebesar 1 persen, maka akan menambah kemiskinan sebesar 0,05 persen di Kabupaten Magelang. Dari hasil diatas maka dapat dikatakan bahwa H4 diterima dimana ada pengaruh yang signifikan antara nilai investasi terhadap kemiskinan di Kabupaten Magelang.

Hasil menunjukkan bahwa variabel $\mathrm{X}^{5}$ yaitu nilai produksi pada usaha industri kecil menengah (IKM) tidak memiliki pengaruh yang signifikan terhadap kemiskinan di Kabupaten Magelang dengan nilai prob. t-stat sebesar 0,09. Hal ini tidak sejalan dengan penelitian [13] yang menyatakan bahwa produktivitas pada usaha industri kecil menengah memiliki pengaruh dalam pengentasan kemiskinan. Dari hasil diatas maka dapat dikatakan bahwa H5 ditolak dimana hasil menunjukkan bahwa tidak ada pengaruh yang signifikan antara nilai produksi terhadap kemiskinan di Kabupaten Magelang.

Secara bersama-sama, keseluruhan variabel yaitu jumlah usaha industri kecil menengah (IKM), penyerapan tenaga kerja, tingkat pendidikan formal, nilai investasi dan nilai produksi memiliki pengaruh yang signifikan terhadap kemiskinan di Kabupaten Magelang. Maka dapat dikatakan bahwa H6 diterima, dimana ternyata ada pengaruh yang signifikan antara keseluruhan variabel independen secara bersama-sama terhadap kemiskinan di Kabupaten Magelang. Hal ini juga menunjukkan bahwa dengan sinergitas antar variabel, mampu mengupayakan pengentasan kemiskinan di kabupaten ini. Hanya bagaimana pemerintah daerah dapat bertindak untuk memberikan kebijakan yang sesuai dalam pengoptimalan keseluruhan variabel tersebut sebagai upaya pengentasan kemiskinan.

\section{KESIMPULAN}

Hasil menunjukkan bahwa variabel $\mathrm{X}_{1}$ yaitu jumlah usaha industri kecil menengah (IKM) memiliki pengaruh yang signifikan terhadap kemiskinan di Kabupaten Magelang. Peningkatan jumlah usaha industri kecil menengah (IKM) sebesar 1 persen, akan mengurangi kemiskinan sebesar 0,51 persen di Kabupaten Magelang. Juga didukung oleh data yang menunjukkan bahwa selama 20 tahun terakhir tampak terjadi penurunan kemiskinan dan peningkatan jumlah usaha industri kecil menengah di kabupaten ini.

Hasil menunjukkan bahwa variabel $\mathrm{X}_{2}$ yaitu penyerapan tenaga kerja memiliki pengaruh yang signifikan terhadap kemiskinan di Kabupaten Magelang. Peningkatan penyerapan tenaga kerja pada usaha industri kecil menengah sebesar 1 persen, akan mengurangi kemiskinan sebesar 1,20 persen di Kabupaten Magelang. Juga didukung oleh data yang ada, bahwa memang selama 20 tahun terakhir, kemiskinan berkurang dan penyerapan tenaga kerja di usaha Industri Kecil Menengah terus mengalami peningkatan. Pengurangan kemiskinan sebesar 1,20 persen setiap kenaikan penyerapan tenaga kerja pada IKM adalah nilai yang cukup besar. Jika penyerapan pada IKM dapat dimaksimalkan, bukan tidak mungkin kabupaten magelang dapat meraih target persentase kemiskinan di angka 9 persen atau mungkin bisa lebih kecil dari 9 persen.

Hasil menunjukkan bahwa variabel $\mathrm{X}_{3}$ yaitu tingkat pendidikan formal tidak memiliki pengaruh yang signifikan terhadap kemiskinan di 
Kabupaten Magelang. Hasil ini memberikan penjelasan bahwa tingkat pendidikan formal seseorang masyarakat, tidak berpengaruh dalam pengentasan kemiskinan. Hal ini dikarenakan seberapa tinggi atau rendahnya tingkat pendidikan formal masyarakat. Kemiskinan dapat ditepis dengan memiliki pekerjaan yang sesuai dengan jenjang pendidikannya.

Hasil menunjukkan bahwa variabel $\mathrm{X}_{4}$ yaitu nilai investasi pada usaha industri kecil menengah (IKM) memiliki pengaruh yang signifikan terhadap kemiskinan di Kabupaten Magelang. Sedangkan hasil menunjukkan bahwa variabel $\mathrm{X}_{5}$ yaitu nilai produksi pada usaha industri kecil menengah (IKM) tidak memiliki pengaruh yang signifikan terhadap kemiskinan di Kabupaten Magelang.

Secara bersama-sama, keseluruhan variabel yaitu jumlah usaha industri kecil menengah (IKM), penyerapan tenaga kerja, tingkat pendidikan formal, nilai investasi dan nilai produksi memiliki pengaruh yang signifikan terhadap kemiskinan di Kabupaten Magelang. Hal ini menunjukkan bahwa dengan sinergitas antar variabel, mampu mengupayakan pengentasan kemiskinan di kabupaten ini. Hanya bagaimana pemerintah daerah dapat bertindak untuk memberikan kebijakan yang sesuai dalam pengoptimalan keseluruhan variabel tersebut sebagai upaya pengentasan kemiskinan.

Saran bagi peneliti selanjutnya, diharapkan agar hasil penelitian dapat dijadikan sebagai pengetahuan yang dapat memberikan kemajuan bagi Kabupaten Magelang secara khusus serta bagi daerah-daerah lainnya secara umum. Bagi pemangku kebijakan, diharapkan agar penelitian ini dapat dijadikan sumber referensi dalam mengupayakan pengentasan kemiskinan di daerah-daerah dengan berbagai mengupayakan berbagai bentuk kebijakan yang mengarahkan kepada pengentasan kemiskinan. Bagi Pembaca, diharapkan agar hasil penelitian ini dapat dijadikan sumber informasi dan dapat ditinjau lebih jauh terkait variabel-variabel yang mampu mengentaskan kemiskinan di Kabupaten Magelang.

\section{REFERENSI}

[1] I. M. T. Wirawan and S. Arka, "Analisis pengaruh pendidikan, PDRB per kapita, dan tingkat pengangguran terhadap jumlah penduduk miskin Provinsi Bali," E-Jurnal EP, vol. 4, no. 5, pp. 546-560, 2015 .

[2] A. Khomsan, A. H. Dharmawan, Saharuddin, Alfiasari, H. Syarief, and D. Sukandar, Indikator Kemiskinan dan Misklasifikasi Orang Miskin. Jakarta: Yayasan Pustaka Obor Indonesia, 2015.

[3] BPS, "Garis Kemiskinan dan Penduduk Miskin di Kabupaten Magelang," BPS Kabupaten Magelang, 2019. [Online]. Available:

https://magelangkab.bps.go.id/statictable/ 2019/10/24/702/garis-kemiskinan-danpenduduk-miskin-di-kabupatenmagelang-2014-2018.html. [Accessed: 26-Nov-2019].

[4] BPS, "Persentase Penduduk Miskin Menurut Provinsi," BPS Kabupaten Magelang, 2019. [Online]. Available: https://www.bps.go.id/dynamictable/201 6/08/18/1219/persentase-pendudukmiskin-menurut-provinsi-2007--2019.html. [Accessed: 26-Nov-2019].

[5] Bappeda, "Pengentasan Kemiskinan Melalui Pemberdayaan Masyarakat Miskin," Badan Perencanaan Pembangunan Daerah Kab. Magelang, 2019. [Online]. Available: http://bappeda.magelangkab.go.id/home/ detail/pengentasan-kemiskinan-melaluipemberdayaan-masyarakat-miskin/43. [Accessed: 26-Nov-2019].

[6] A. Widodo, "Koordinasi Penanggulangan Kemiskinan Kabupaten Magelang Tahun 2017," Badan Perencanaan 
Pembangunan Daerah Kab. Magelang, 2017. [Online]. Available: http://bappeda.magelangkab.go.id/v2/ho me/detail/rapat-koordinasipenanggulangan-kemiskinan-kabupatenmagelang-tahun-2017/128. [Accessed: 26-Nov-2019].

[7] R. A. Syahputra, "Analisis implementasi pemberdayaan masyarakat melalui program revitalisasi posyandu, pemberdayaan nelayan dan bantuan ekonomi wirausaha di kecamatan Medan Labuhan Kota Medan," J. Pembang. Perkota., vol. 6, no. 2, pp. 82-90, 2018.

[8] F. Anggraeni, "Pengembangan usaha mikro, kecil dan menengah (UMKM) melalui fasilitasi pihak eksternal dan potensi internal (studi kasus pada kelompok usaha 'Emping Jagung' di kelurahan Pandanwangi kecamatan Blimbing Kota Malang)," J. Adm. Publik Mhs. Univ. Brawijaya, vol. 1, no. 6, pp. 1286-1295, 2013.

[9] A. A. Sokoto and Y. Z. Abdullahi, "Strengthening small and medium enterprises (SMEs) as a strategy for poverty reduction in North Western Nigeria," Am. J. Humanit. Soc. Sci., vol. 1, no. 3, pp. 189-201, 2013.

[10] A. A. Odeyana and E. O. Adu, "Small and medium enterprises (SMEs) as a means of creating employment and poverty reduction in Fort Beaufort, Eastern Cape province of South Africaitle," J. Soc. Sci., vol. 45, no. 1, pp. 8-15, 2015.

[11] A. Mamman, A. M. Kanu, A. Alharbi, and N. Baydoun, Small and medium-sized enterprises (SMEs) and poverty reduction in Africa: Strategic management perspective, First Edit. Inggris: Cambridge Scholars Publishing, 2015.

[12] J. M. Simamora, Z. Zein, and F. Rahmadana, "The effect of micro, small and medium enterprises, labor absorption and non formal education level to decrease the poverty in Simalungun district," in 3rd Annual International Seminar on Transformative Education and Educational Leadership (AISTEEL 2018), 2018, vol. 200, pp. 71-75.

[13] T. Tambunan, "Peran usaha mikro dan kecil dalam pengentasan kemiskinan di daerah," J. Bina Praja, vol. 4, no. 2, pp. 73-92, 2012.

[14] I. Maipita and Fitrawaty, Mengukur Kemiskinan dan Distribusi Pendapatan. Yogyakarta: UPP STIM YKPN, 2014.

[15] I. Maipita, "Simulasi dampak kenaikan upah minimum terhadap tingkat pendapatan dan kemiskinan," Ekuitas J. Ekon. dan Keuang., vol. 17, no. 3, pp. 391-410, 2013.

[16] Arum, "Analisis penyerapan tenaga kerja pada sektor industri besar dan sedang seeks karesidenan Surakarta tahun 2006 2013," Universitas Muhammadiyah Surakarta, Surakarta, 2016.

[17] Ali and Abdel, "Entrepreneurship development and poverty reduction," Am. Int. J. Soc. Sci., vol. 2, no. 3, pp. 108-113, 2013.

[18] N. A. Maizunati, "Optimalisasi peran pendidikan dasar dalam mengentaskan kemiskinan di kabupaten Klaten," J. REP (Riset Ekon. Pembangunan), vol. 3, no. 2, pp. 358-368, 2018.

[19] Fauziah, "Analisis penyerapan tenaga kerja pada industri kecil dan menengah (IKM) di kota Palu periode 2000-2013," e-Jurnal Katalogis, vol. 3, no. 1, pp. 138146, 2015.

[20] S. U. E. Hadiyanti, "Pengaruh investasi pada industri kecil dan industri menengah terhadap penyerapan tenaga kerja di kota 
Jurnal EK\&BI, Volume 4, Nomor 1 Juni 2021

E-ISSN: 2621-4695

DOI 10.37600/ekbi.v4i1.216

Samarinda," Jiep, vol. 15 , no. 2, pp. $32-$ 55, 2015. 